\title{
First xenacanthid shark from the Pennsylvanian (Moscovian) of the Northern Caucasus (Russia)
}

\author{
Oliver Hampe ${ }^{*, 1}$ and Alexander Ivanov ${ }^{* *, 2}$ \\ ${ }^{1}$ Museum für Naturkunde der Humboldt-Universität zu Berlin, Invalidenstraße 43, D-10115 Berlin, Germany \\ 2 Department of Palaeontology, St. Petersburg University, 16 Linija 29, St. Petersburg 199178, Russia
}

Received 18 December 2006, accepted 21 February 2007

Published 1 August 2007

With 5 figures, 1 table

Key words: Triodus, teeth, systematics, Northern Caucasus, Pennsylvanian.

\begin{abstract}
The occurrence of Triodus teberdaensis n. sp. teeth from the Pennsylvanian Tolstiy Bugor Formation (Moscovian) of KarachayCherkess Republic is the first evidence of xenacanthid remains from the Caucasus. The new species was found in carbonate sediments interpreted as resulting from short-term transgressions during the Pennsylvanian regressive phase - further evidence that xenacanthids, predominantly adapted to freshwater, have also lived in marine environments.
\end{abstract}

Schlüsselwörter: Triodus, Zähne, Systematik, Nordkaukasus, Oberkarbon.

\section{Zusammenfasung}

Das Auftreten von Zähnen des Triodus teberdaensis n. sp. in der oberkarbonischen Tolstiy Bugor Formation (Moscovium) von Karatschai-Tscherkessien ist der erste Nachweis xenacanthider Überreste aus dem Kaukasus. Die neue Art wurde in karbonatischen Sedimenten, die als Transgressions-Intervalle innerhalb der globalen Oberkarbon-Regression interpretiert werden, abgelagert - ein Beleg dafür, dass die überwiegend aus Süßwasserablagerungen bekannten Xenacanthiden auch im marinen Milieu lebten.

\section{Introduction}

Palaeozoic chondrichthyans are poorly known from the Caucasus. They are documented so far from Famennian sediments of the Northern Caucasus, Russia (Ivanov 2003), from late Famennian deposits of the Transcaucasus, Nakhichevan/Azerbaijan (Lebedev 2005), and from late Frasnian to early Tournaisian rocks of south-western Armenia (Hairapetian et al. 2005).

Xenacanthid teeth have been found for the first time in the marine interbedding of Pennsylvanian age from the Teberda River, Northern Caucasus,
Karachay-Cherkess Republic, Russia (Fig. 1). The studied teeth were obtained from acid-dissolved samples collected for their microfauna. The specimens are stored in the Palaeontological Museum of St. Petersburg University, Russia.

The Caucasian teeth belong to the well-known genus Triodus erected by Jordan (1849) and show a specific combination of characters that differ from other known species of the genus. Many Triodus species are also known from complete skeletons, especially from the latest Gzhelian to lower Artinskian sediments of the SW German Saar-Nahe Basin (Kner 1867; Fritsch 1890; Schneider \& Zajíc 1994;

\footnotetext{
* Corresponding author: e-mail: oliver.hampe@museum.hu-berlin.de

** E-mail: elasmo2004@yandex.ru
} 

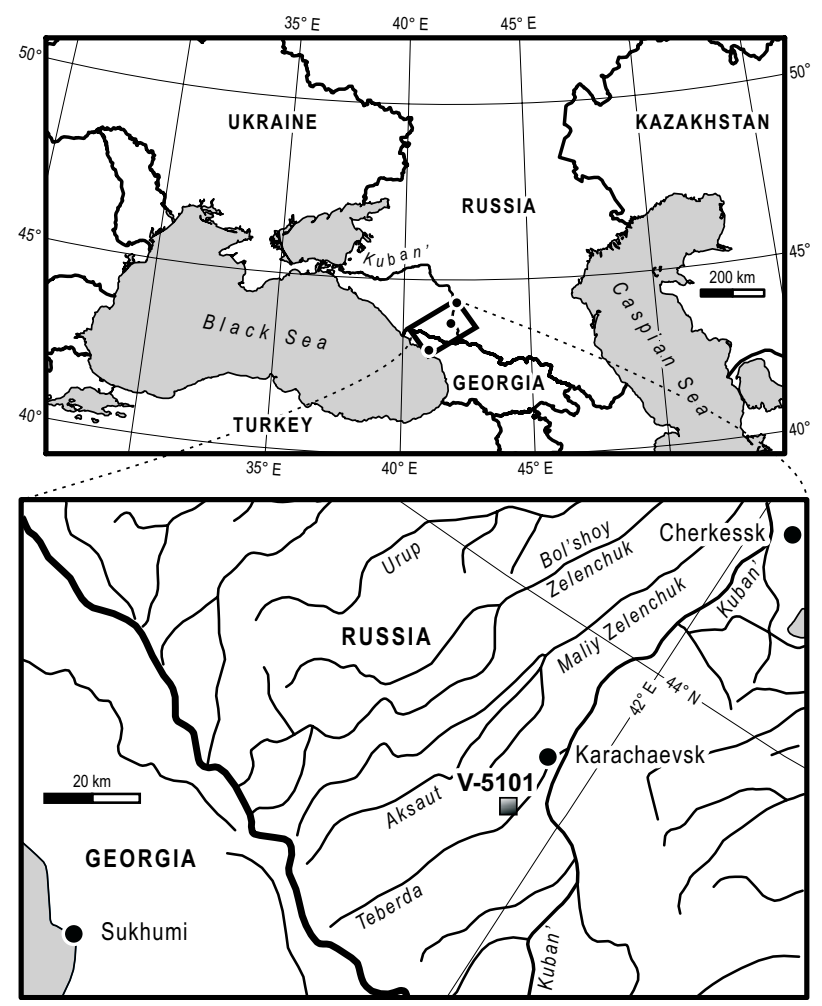

Fig. 1. Map of the area around Black and Caspian Seas with a detail of Karachay-Cherkess Republic/Russia near the border to Georgia showing the location of the collecting site at Teberda River (V-5101, square).

Heidtke et al. 2004). However, the differences between the skeletal remains are minimal, such that a cladistic analysis with characters based on tooth morphology certainly helps to clarify the interspecific relationship.

The cladistic analysis was performed using the programs WINCLADA (Nixon 2002) and NONA (Goloboff 1999).

\section{Locality data}

The locality V-5101 (lettering of the North-Caucasus Production Geological Corporation, Essentuki) is situated on the left bank of the Teberda River at the mouth of the Gimaldyk River in the low stream from Verkhnyaya Teberda village (Fig. 2). It is around $20 \mathrm{~km}$ south of the town of Karachaevsk in the Karachay-Cherkess Republic, Northern Caucasus, Russian Federation. The investigated area belongs to the Teberda Syncline in the western part of the Peredovoy ("Front") Ridge of Caucasus Mountains, which is known as a folded area and active tectonic zone.

The xenacanthid teeth were found in the upper member of the Tolstiy Bugor Formation. The lower member of the formation corresponds with the Bashkirian but the upper member is Moscovian, Pennsylvanian ( $=$ Middle Carboniferous of the Russian Stratigraphical Chart). The members are correlated accordingly with the Westphalian A-B and the Westphalian $\mathrm{C}$ based on their floral assemblages (Belov \& Kizevalter 1962). The deposits of the Tolstiy Bugor Formation consist of clastic rocks such as siltstone, mudstone, sandstone, clay shale and siliceous shale interbedded with the minor layers of volcanic rocks (tuff and tuffaceous sandstone), carbonates (marl and sandy limestone) and coal shale (Pogrebnov 1975; Savin 1984).

The upper member of the Tolstiy Bugor Formation yields plant remains, ostracodes, some bivalves, foraminifers, and fish remains. The latter includes the Triodus teeth described here, a fragment of a rhizodontid scale, and palaeoniscoid scales. The Triodus teeth occur in one of the marl intercalations. The interbedded carbonates of the Tolstiy Bugor Formation are the result of short-term transgressive phases within the Pennsylvanian regression.

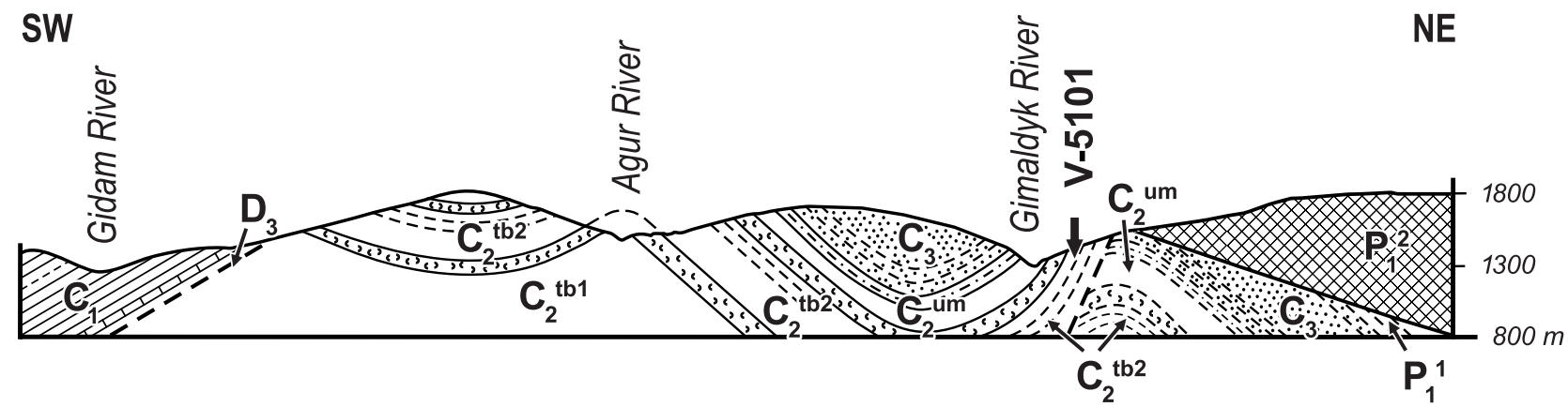

Fig. 2. Schematic section of the left bank of Teberda River (based on Pogrebnov 1975). The arrow shows the position of locality V-5101, where the new Triodus species was discovered. $\mathbf{D}_{\mathbf{3}}$ and $\mathbf{C}_{\mathbf{1}}-$ undetermined Upper Devonian; $\mathbf{C}_{\mathbf{2}} \mathbf{b}-$ lower and $\mathbf{C}_{\mathbf{2}}^{\mathbf{t b 2}}$ - upper member of Tolstiy Bugor Formation; $\mathbf{C}_{\mathbf{2}}^{\mathbf{m u}}-$ Maliy Urup Fm.; $\mathbf{C}_{\mathbf{3}}-$ Karadzhelmass and Gremuchinskaya Fm. (Pennsylvanian); $\mathbf{P}_{1}^{1}-$ Aksaut Formation; $\mathbf{P}_{1}^{2}-$ Gidamlyk Formation (Permian). 


\section{Systematic Palaeontology}

Class Chondrichthyes Huxley, 1880

Subclass Elasmobranchii Bonaparte, 1838

Superorder Xenacanthimorpha Berg, $1940=$ Xenacanthi Glikman, 1964

Order Xenacanthiformes Berg, $1940=$ Xenacanthida Glikman, 1964

Family Xenacanthidae Fritsch, 1889

Genus Triodus Jordan, 1849

\section{Triodus teberdaensis n. sp.}

Fig. 3

\section{Xenacanthus Ivanov, p. 28}

Derivation of name. After Teberda River in the Northern Caucasus, Russian Federation.

Holotype. MP SPGU 43-1, tooth.
Type locality. V-5101, Teberda River, at the mouth of Gimaldyk River around $20 \mathrm{~km}$ southwest of Karachaevsk town, Peredovoy Ridge of Northern Caucasus, Karachay-Cherkess Republic, Russian Federation.

Formation and age. Upper member of the Tolstiy Bugor Formation; Moscovian, Pennsylvanian.

Referred specimens. MP SPGU 43-2, tooth; MP SPGU 43-3, fragment of tooth.

Diagnosis. A species of Triodus with the following characteristcs: lateral cusps of greater cross-section than the median cusp; length of median cusp $3 / 4$ to $4 / 5$ that of the laterals; 4-5 vertical cristae per lateral cusp, without any bifurcations or split-offs, which run nearly the entire length of the cusps, and some of which do not reach the distal tips; base with circular or slightly diamond-shaped coronal button; upper side with different sized shaft; median foramen present lingual to the median cusp; basal tubercle without shaft; lateral angle between crown and base $90^{\circ}$ to $100^{\circ}$.

Description. The extremely small teeth from the Tolstiy Bugor Formation have a height of only

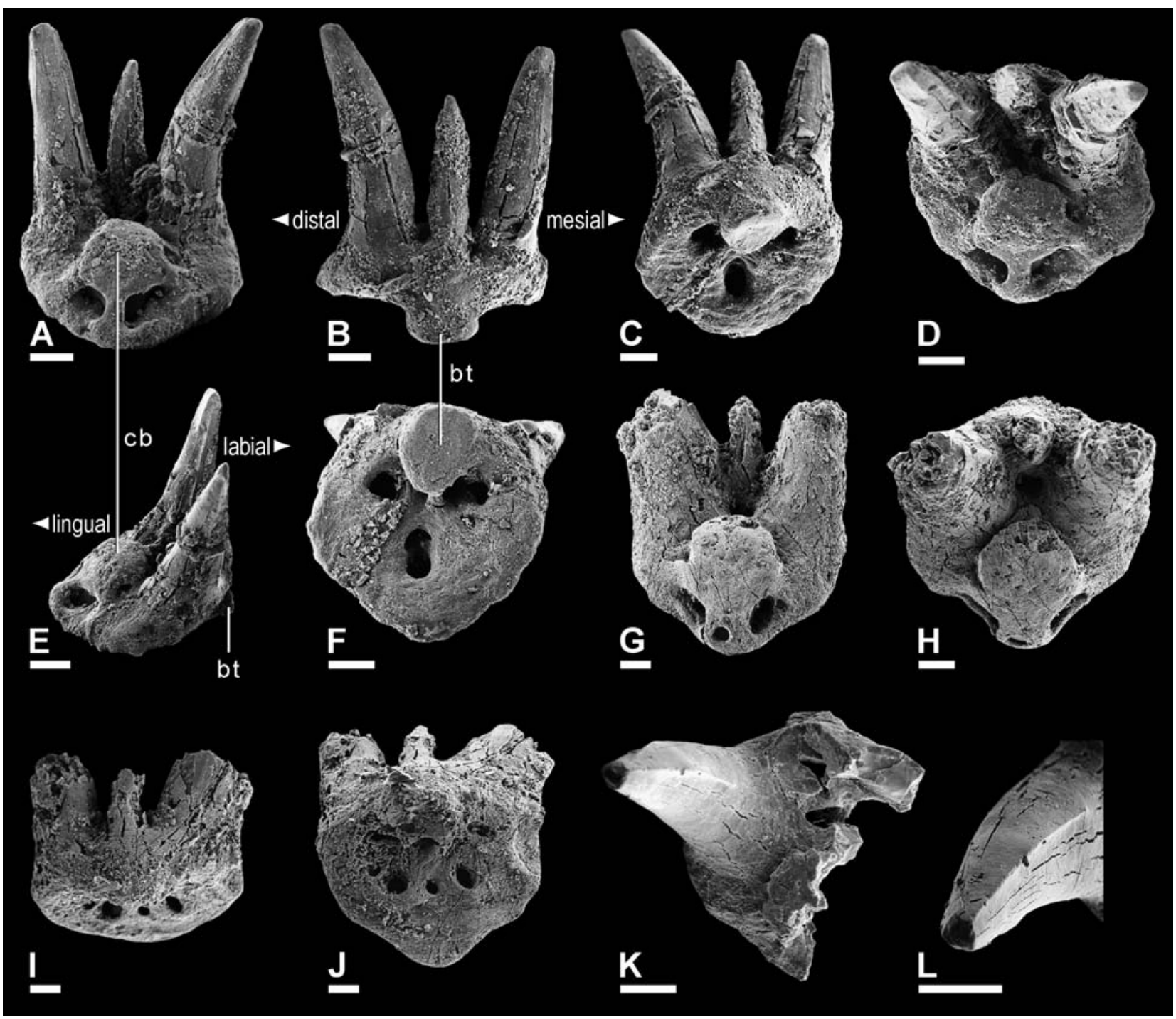

Fig. 3. Teeth of Triodus teberdaensis n. sp., Tolstiy Bugor Formation, Moscovian of Karachay-Cherkess Republic, Russia. MP SPGU 43-1, holotype. A - lingual; B - labial; C - baso-labial; D - coronal; E - corono-lateral; F - basal views. MP SPGU 43-2: G - lingual; H - coronal; I - labial; J - basal views. MP SPGU 43-3, a broken tooth: K - coronal view; $\mathbf{L}$ - detail of the lateral cusp. bt - basal tubercle; ct - coronal button. Scale $=100 \mu \mathrm{m}$. 
$700 \mu \mathrm{m}$ on average. Their crowns consist of three cusps as is usual for xenacanthid teeth. All cusps are pointed and arranged in a mesio-distal row (Fig. 3D). The two lateral cusps have a larger crosssection and are relatively straight without pronounced curvature (Fig. 3A, B, G, H, I). The median cusp reaches $3 / 4$ to $4 / 5$ of the height of the lateral cusps (Fig. 3A, B). The tiny teeth show four or five vertical cristae per lateral cusp (Fig. 3K, L). No bifurcations or split-offs of the cristae could be observed. The cristae occupy nearly the entire length of the cusps, however, not all reach the cusp apex. Laterally situated cristae imply cutting edges (Fig. 3E), but the cross-section of the cusps is more or less rounded. A labio-lingual compression is not shown. The preservation of the teeth is rather good although acid preparation has caused several vertical cleavages.

The base of Triodus teberdaensis n. sp. is somewhat rounded. There is no labio-lingual or mesiodistal elongation (Fig. 3F, J). The most lingual part may be a little pronounced, supporting a thicker shaft on the upper side of the base (Fig. 3G, H). The coronal button is circular or slightly diamondshaped (Fig. 3D, H). Two larger nutrient foramina with elongated outlines are situated in the laterolingual corners of the coronal button, flanking the lingual shaft (Fig. 3A, D, E, G, H). The larger tooth with a broader shaft shows a small, lingual foramen on the shaft (Fig. 3G). A median foramen is present lingual to the median cusp (Fig. 3D, H).

The basal aspect shows a relatively small but prominent and rounded basal tubercle with a slight basal depression (Fig. 3B, C, F). Three to seven nutrient foramina are concentrated in the centre of the basal surface (Fig. 3F, J). The base is slightly depressed.

The lateral angle between the crown and base is about $90^{\circ}$ to $100^{\circ}$.

Extended discussion. Triodus teberdaensis n. sp. shares all typical generic characteristics of Triodus which are as follows: tricuspid crown with cusps of rounded to polygonal cross-section, a comparatively long median cusp, the presence of exclusively straight vertical cristae (among others, Hampe 2003).

The diagnostic features of the genus Xenacanthus such as the usual presence of lanceolate cusps and the consistently larger number of nutrient foramina that perforate the base are not developed in Triodus teberdaensis n. sp. (Hampe 1988, 1997, 2003). However, there are a few similarities with older representatives of Xenacanthus. Teeth of X. elegans (Hampe 2003: fig. 14a-f) from Midlothian, Scotland (Pendleian, Serpukhovian), are a little bigger measuring between 1.8 to $2.5 \mathrm{~mm}$. Similarities with the Caucasian Triodus are the more or less parallel arrangement of the cusps, the presence of a median foramen lingual to the median cusp as well as the general low number of nutrient foramina on the upper side of the base (1-4 in X. elegans). The bottom side of X.elegans teeth is also concavely depressed and the number of nutrient foramina is nearly the same (usually 2-8). Striking differences to Triodus teberdaensis $\mathrm{n} . \mathrm{sp}$. are the absence of vertical cristae, a tongue-shaped coronal button with a lateral constriction, a different arrangement of the foramina on the bottom side, a basal tubercle with lingually directed shaft and a lateral angle between crown and base of $130^{\circ}$ to $135^{\circ}$.

The small teeth of $X$.parallelus from the Westphalian D (Moscovian) sediments of Nyřany and Třemošná (Plzen Basin, Czech Republic, see Zajíc \& Štamberg 1985) are unfortunately poorly illustrated in Schneider \& Zajíc (1994: fig. 17; pl. 3, fig. 1a, b) but have minor similarities with Triodus teberdaensis $\mathrm{n}$. $\mathrm{sp}$. They have only the presence of a long median cusp (here: exactly $3 / 4$ that of the laterals), a rounded coronal button supported by a lingual shaft and the $90-100^{\circ}$ angle between the crown and base in common. X. parallelus differs from the Caucasian Triodus with a tooth height of $1 \mathrm{~mm}$ to a maximum of $2 \mathrm{~mm}$, lanceolate cusps with smooth lateral edges as is typical for the genus Xenacanthus, a regular mesio-distally broadened base, 2-6 nutrient foramina on the upper side of the base and a labially extended basal tubercle.

The teeth of the Gzhelian Xenacanthus remigiusbergensis (Hampe 1994: fig. 8, 9) from the German Saar-Nahe Basin are also very small representatives of the Xenacanthidae (only 400 to $900 \mu \mathrm{m}$ high). However, the nearly identical length of the median cusp and the presence of a median foramen are the only similarities with the teeth of Triodus teberdaensis n. sp. Other features of $X$. remigiusbergensis differ clearly from the Caucasian Triodus: the distal curvature of the cusps, their lanceolate cross-section, the extremely flat and oval-shaped base, the small and flat coronal button, the lower number of foramina on the bottom side (4-5), and the lateral angle between crown and base which can reach up to $140^{\circ}$.

The Westphalian (Bashkirian to Moscovian) Xenacanthus laevissimus from Britain (Hampe 2003: fig. 15d) and the Autunian (Asselian) Xenacanthus humbergensis from the Saar-Nahe Basin (Hampe 1988: fig. 4, 1994: fig. 13a-c) are the only species of Xenacanthus known so far which can occasionally develop a few vertical cristae - a key character of the genus Triodus.

Triodus serratus (Hampe 2003: fig. 19d-h, $20 \mathrm{a}-\mathrm{p}$ ) from the Westphalian (Bashkirian to Moscovian) deposits of England and Scotland has the largest teeth of the genus reaching up to $5 \mathrm{~mm}$ in height. They are completely different to those of Triodus teberdaensis $\mathrm{n}$. sp., especially regarding their intercuspidal proportions, the arrangement and numbers of cristae, and the shape of the base (Hampe 2003: 221f.). 
Triodus lauterensis (Hampe 1989: fig. 3) from the Saar-Nahe Basin (upper Stephanian A to lowermost Rotliegend: middle Kasimovian to late Gzhelian) possesses the most primitive character states of all Triodus species (see Phylogenetic implications). It has larger teeth (height $1-2.5 \mathrm{~mm}$ ) than the Karachay-Cherkessian species and generally has a base with a larger number of nutrient foramina (5-8 on the upper side; $4-8$ on the bottom side). The angle between crown and base is larger $\left(100^{\circ}-110^{\circ}\right)$ than that of the teeth of Triodus teberdaensis n. sp. Only a few affinities are documented between this German and the Caucasian species: a longer median cusp (1/2 to $4 / 5$ of the laterals in Triodus lauterensis teeth) and a higher number of vertical cristae. Bifurcations are not common on the teeth of Triodus lauterensis. A shaft can also occur in Triodus lauterensis. Both species have a prominent basal tubercle, but one which is comparatively smaller in the Caucasian teeth.

Triodus palatinus (Hampe 1989: fig. 4) from the Saar-Nahe Basin (lower Rotliegend: latest Gzhelian and early Asselian) has larger teeth $(1-3 \mathrm{~mm}$ in height) than Triodus teberdaensis n. sp., which possesses a median cusp $1 / 2$ to $3 / 4$ the length of the lateral cusps, and are therefore shorter on average than the Caucasian Triodus. The number of 6-9 vertical cristae on the lateral cusps is higher in Triodus palatinus. The cristae show irregular and dichotomous bifurcations, which is not the case in Triodus teberdaensis n. sp. The lateral angle between crown and base can be larger (up to $120^{\circ}$ ) in the teeth of Triodus palatinus. The base of Triodus palatinus teeth has a larger number of nutrient foramina (3-6) on the upper side than in Triodus teberdaensis n. sp. Both species possess a lingual shaft, and the 3-6 of nutrient foramina of Triodus palatinus on the bottom side is within the range of the new Karachay-Cherkessian species.

The early Asselian Triodus obscurus (Hampe 1989: fig. 5) is another species from the SW German Saar-Nahe Basin. Triodus obscurus developed larger teeth (1-2 mm height) and the median cusp is smaller than in the Caucasian teeth, only $1 / 2$ to $2 / 3$ the height of the laterals cusps. The arrangement of vertical cristae on the cusps is also different from Triodus teberdaensis n. sp. Triodus obscurus has bifurcating cristae limited to the labial side. Some similarities are documented concerning the base: the coronal button can be equipped with a shaft and the number of nutrient foramina $(2-4$ on the upper side; 3-5 on the bottom side for Triodus obscurus). However, the crown-base angle of Triodus obscurus ranges between $90^{\circ}$ and $120^{\circ}$ and is therefore larger than in the teeth of Triodus teberdaensis n. sp.

The teeth of Triodus teberdaensis n. sp. have nothing in common with the Bohemian species Triodus carinatus (Schneider \& Zajíc 1994: fig. 21/1-13, as Bohemiacanthus) from the basal Autunian deposits (lower Asselian) of Podkrkonoše Basin and Boscovice Furrow concerning size, development of the vertical cristae, shape of coronal button and basal tubercle, the numbers of the nutrient foramina, and the angle between the base and crown. All of the aforementioned tooth characters are different in Triodus carinatus (Schneider \& Zajíc 1994: 123 ff).

The teeth of the morphotype Triodus sp. ZÖ (abbreviation based on the locality Zöbing; Schindler \& Hampe 1996: fig. 2) from Gzhelian rocks of Lower Austria vary between 1 and $2.5 \mathrm{~mm}$ in height. They are also different from the Caucasian teeth in having a shorter median cusp with a height $1 / 2$ to $2 / 3$ that of the lateral cusps and bearing about 6 vertical cristae of variable length (Schindler \& Hampe 1996: fig. 2a-c). Furthermore, bifurcations of the cristae are present in the Zöbing teeth, but are not developed in Triodus teberdaensis n. sp. The coronal button of Triodus sp. ZÖ has no lingual shaft. The numbers of nutrient foramina are also slightly different in the Austrian form and the angle between base and crown in lateral view is wider $\left(130^{\circ}-135^{\circ}\right)$. Similarities between Triodus teberdaensis n. sp. and Triodus sp. ZÖ can be observed only in the outline of the base, which is slightly honeycomb-shaped in both, and the presence of a median foramen on the upper side of the base.

Teeth of Triodus sessilis (Hampe 1989: fig. 1) from the SW German Saar-Nahe Basin (lower Rotliegend: lower Asselian) differ from those of Triodus teberdaensis $\mathrm{n}$. sp. in having a larger height (1-2 mm). The German species can have a smaller median cusp but with a minimum height of $2 / 3$ that of laterals and consistently has 6 vertical cristae with a "Y"-shaped bifurcation near the apex of the cusps. The number of nutrient foramina is different (3-9 on upper side; 4-9 on bottom side) from Triodus teberdaensis n. sp. Triodus sessilis shows the following affinities with the Caucasian species: the coronal button is also prominent, the shape is rounded or rhomboid and it is accompanied by a shaft. A peculiar lingual projection of the base (Hampe 1989: fig. 1h) is also present in teeth of both species. The lateral angle between base and crown is nearly constantly $90^{\circ}$ in Triodus sessilis and the angle is similar in Triodus teberdaensis n. sp. $\left(90^{\circ}-100^{\circ}\right)$.

The Asselian Triodus frossardi from the Autun Basin in France (Soler-Gijón \& Hampe 1998: fig. 4) has larger teeth $(1-1.8 \mathrm{~mm})$ and a higher number of bifurcating labial vertical cristae. The base in the French teeth is elongated slightly labio-linguad and the number of nutrient foramina is lower (about 4). The Karachay-Cherkessian species shares with Triodus frossardi the long and slender median cusp, the presence of a short shaft lingual to the coronal button and a $90^{\circ}-95^{\circ}$ angle between base and the crown.

Triodus kraetschmeri (Hampe 1989: fig. 6) from the Saar-Nahe Basin (lowermost upper Rotliegend: 
middle Asselian to lower Artinskian) has the highest affinity with Triodus teberdaensis $\mathrm{n}$. $\mathrm{sp}$. The teeth of the SW German species are also quite small, being $1 \mathrm{~mm}$ or less in height. The median cusp is very long ( $>3 / 4$ that of the laterals) and fewer (5-6) vertical cristae are developed. However, the cristae have "Y"-shaped bifurcations near the apex, a character, that cannot be confirmed in the Russian teeth. In Triodus kraetschmeri the cusps form an "occlusal triangle", with a labially extended median cusp. This occlusal triangle is less developed in the Caucasian specimens. A lingual shaft can also be present in T. kraetschmeri, and the number of nutrient foramina is similar in both species. With only 2-4 foramina on the bottom side, T. kraetschmeri exhibits fewer apertures than Triodus teberdaensis n. sp. The lateral angle is constantly $100^{\circ}$, which is not remarkably different from that of the Russian species. Quadricuspidate teeth or bicuspid commissurals (see Hampe 1997: fig. 4-6) are not yet known from Triodus teberdaensis $\mathrm{n}$. $\mathrm{sp}$.

There are recent notes on Triodus teeth occuring in the Permocarboniferous of the Sardinian Perdasdefogu Basin (Freytet et al. 2002; Fischer et al. 2003; Schneider et al. 2003). However, information on the remains is still too poor to adequately compare with the newly discovered Caucasian teeth (Schneider et al. 2003: fig. 1). Soler-Gijón (1993, 1999) presented a new species of Triodus of Gzhelian age diagnosed on dental morphology from the Puertollano Basin in Spain that shows closest affinities to T. lauterensis (see Schneider et al. 2000).

Triodus is also known from North American desposits. Teeth were described as "Orthacanthus aff. compressus" by Johnson \& Thayer (1999) from Arizona (late Morrowan: Bashkirian) and by Johnson (1999) from Pennsylvania (lower Wolfcampian: Asselian). Whereas the teeth from Arizona are as yet insufficiently documented (no published figures), Johnson (1999: fig. 20) provided a short description of a small number of the teeth from Pennsylvania which are little higher than $1 \mathrm{~mm}$ and bear a variable number of vertical cristae concentrated on the lingual face of the cusps. The median cusp is shorter than in teeth of Triodus teberdaensis $\mathrm{n}$. sp. The angle between base and crown is quite similar, being $90^{\circ}$ in the American teeth.

\section{Phylogenetic implications}

The following discussion is an attempt to clarify the relationships between Triodus species. The primitive xenacanthid Dicentrodus bicuspidatus from Scotland (early Serpukhovian) is used for outgroup comparison (for characterisation, see Hampe 2003: $201 \mathrm{ff}$.). Nine species and one morphotype are chosen for this phylogenetic analysis. The character sources of the taxa used are given in parentheses:
T. lauterensis, T. palatinus, T. obscurus, T. sessilis, T. kraetschmeri from the Saar-Nahe Basin (Hampe 1989), T. carinatus from Bohemia (Schneider \& Zajíc 1994), T. frossardi from the Autun Basin, France (Soler-Gijón \& Hampe 1998), T. serratus from Britain (Hampe 2003), T. teberdaensis (this paper), and T. sp. ZÖ from Lower Austria (Schindler \& Hampe 1996).

The analysis was executed using an heuristic search setting. A search for trees using the tree bisectionreconnection method of branch-swapping was performed. Thirteen characters [1-13] were selected for discussion, all based on tooth morphology.

Character list:

[1] Height of teeth greater than $1 \mathrm{~mm}(0)$, less than $1 \mathrm{~mm}(1)$

[2] Minimum length of median cusp $<2 / 3$ that of lateral cusps $(0), \geq 2 / 3$ (1)

[3] Median cusp on a level with lateral cusps (0), moved labially (1)

[4] Number of vertical cristae $>6(0), \leq 6$ (1), lack on the lingual side (2)

[5] Dichotomous division or irregular splitting of cristae (0), vertical cristae divided in a Y-shaped pattern near the tip (1)

[6] Vertical cristae can reach the base (0), shorter vertical cristae (1)

[7] Angle between crown and base in lateral view $>100^{\circ}(0),<100^{\circ}(1)$

[8] Dentition heterodontous in size (0), homodontous (1)

[9] Shape of basal tubercle rounded (0), rhomboid (1)

[10] Lingual shaft in front of the coronal button present (0), not present (1)

[11] Number of nutrient foramina on each upper and bottom side $>4(0),<4$ (1)

[12] No pulp cavity developed within the base (0), single pulp cavity present (1)

[13] Base of teeth consists of trabecular dentine (0), base consists of orthodentine (1)

Although it is a general rule of thumb to have at least twice as many characters as taxa (Hammer \& Harper 2006), further meaningful characters could not be ascertained and applicated to describe species of Triodus (see also Hampe 1989). The resulting cladogram consists of a single tree (Fig. 4). Triodus is one of the three genera united in the family Xenacanthidae (see cladograms in Hampe 1995, 2003; Hampe \& Heidtke 1997) of which T. lauterensis is the most primitive representative. All other investigated ingroup taxa differ from T. lauterensis in the apomorphy of the reduced length of the vertical cristae on the cusps, which do not reach the base [6]. T. serratus in a sister group relation with $T$. palatinus developed a basal tubercle of somewhat rhomboid outline [9] which is an autapomorphic character for this British species. More 


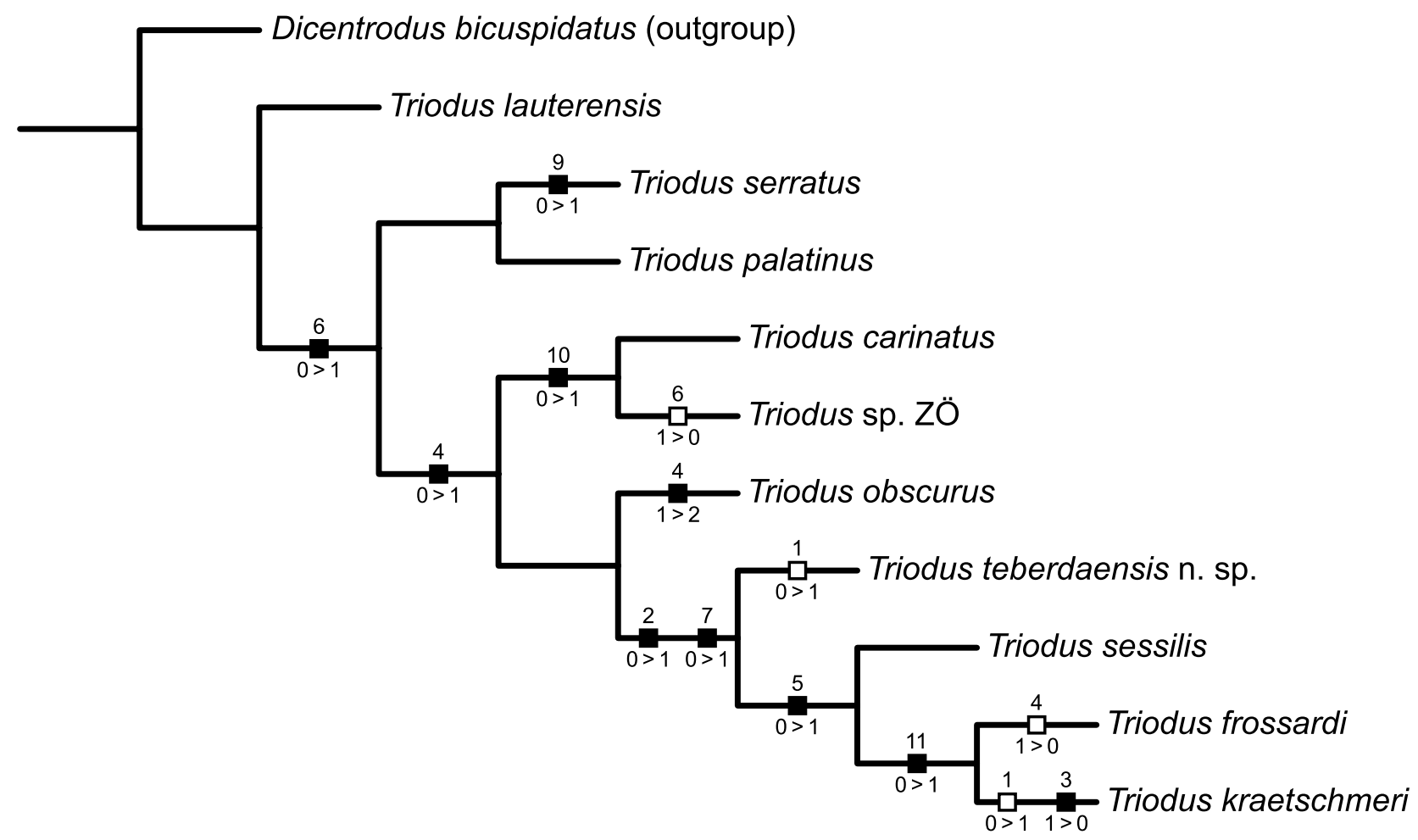

Fig. 4. Phylogenetic analysis of the genus Triodus showing the unambiguous character changes [heuristic search setting with Dicentrodus $($ D. bicuspidatus $=$ only known species) as outgroup; tree length $=17$; consistency index $(\mathrm{CI})=0.820$; retention index $(\mathrm{RI})=0.820]$. The character numbers are placed above the squares, the character states below. Explanations, see text.

derived taxa (node behind T. serratus/T. palatinus) have a reduced number of vertical cristae [4]. Only T. frossardi shows here a reversal.

The presence of some longer cristae $[6 \rightarrow$ reversal] of the morphotype $T$. sp. ZÖ that can reach the base can also be interpreted as a variation in comparison with the Bohemian T. carinatus. Generally strong morphological similarities and their palaeogeographic vicinity can lead to the assumption that the two may be conspecific. The lack of a lingual shaft on the base [10] is apomorphic to both forms. The total lack of vertical cristae on the lingual side of the cusps [4] is unique for teeth of T. obscurus.

The ascending branch including T.teberdaensis, T. sessilis, T. frossardi and T. kraetschmeri are characterised by an increased length of the median cusp [2] and a lateral angle between the base and crown below $100^{\circ}$ [7]. Y-shaped divisions of the cristae near the tip of the cusps is an apomorphy of T. sessilis and its sister group containing $T$. frossardi and T. kraetschmeri [5] which are grouped by the apomorphic character of a reduced basal vascularisation with a low number of nutrient foramina [11]. The small height of T. teberdaensis and T. kraetschmeri must be considered a homoplastic feature [1]. One autapomorphy characterises T. kraetschmeri: the labially displaced median cusp [3] forming a triangle with the tips of the laterals in occlusal view.

Whereas the monophyly of the Xenacanthidae (including Xenacanthus, Triodus, Plicatodus) is beyond doubt (Hampe 2003), the monophyly of Triodus should be still considered under debate; several of the characters also occur in Xenacanthus, for example, the key feature of the presence of vertical cristae in the Bashkirian/Moscovian X. laevissimus and the Asselian X.humbergensis (Hampe 1988, 1994, 2003).

\section{Conclusions}

Traditionally, xenacanthids are considered to be freshwater elasmobranchs (Zangerl 1981). However, the teeth of the new species Triodus teberdaensis were embedded in marine sediments. Considerations of the palaeogeographical situation of the localities with Triodus occurrences reveal also the possiblity of temporary marine influences in different basins.

Vai (2003: fig. 6) and Wells et al. (2005: fig. 8) propose a shallow environment with fluctuating salinities for the British area in the Pennsylvanian when T. serratus was living. The palaeogeographic vicinity of Boscovice Furrow and Podkrkonoše Basin (T. carinatus) to the southern coast (Palaeotethys) during the Carboniferous (Ziegler 1989: pl. 8; Schultze \& Soler-Gijón 2004: fig. 4) indicates the possibility of a temporary marine influence, which has also been discussed for the Alpine area to which the Zöbing locality (morphotype T. sp. ZÖ) belongs (Schindler \& Hampe 1996; Blieck et al. 1997). The influence of epicontinental seas has also been suggested for the basinal structures of the French Central Massif (Heyler \& Poplin 1988; Crônier \& Courville 2005) (T. frossardi). 


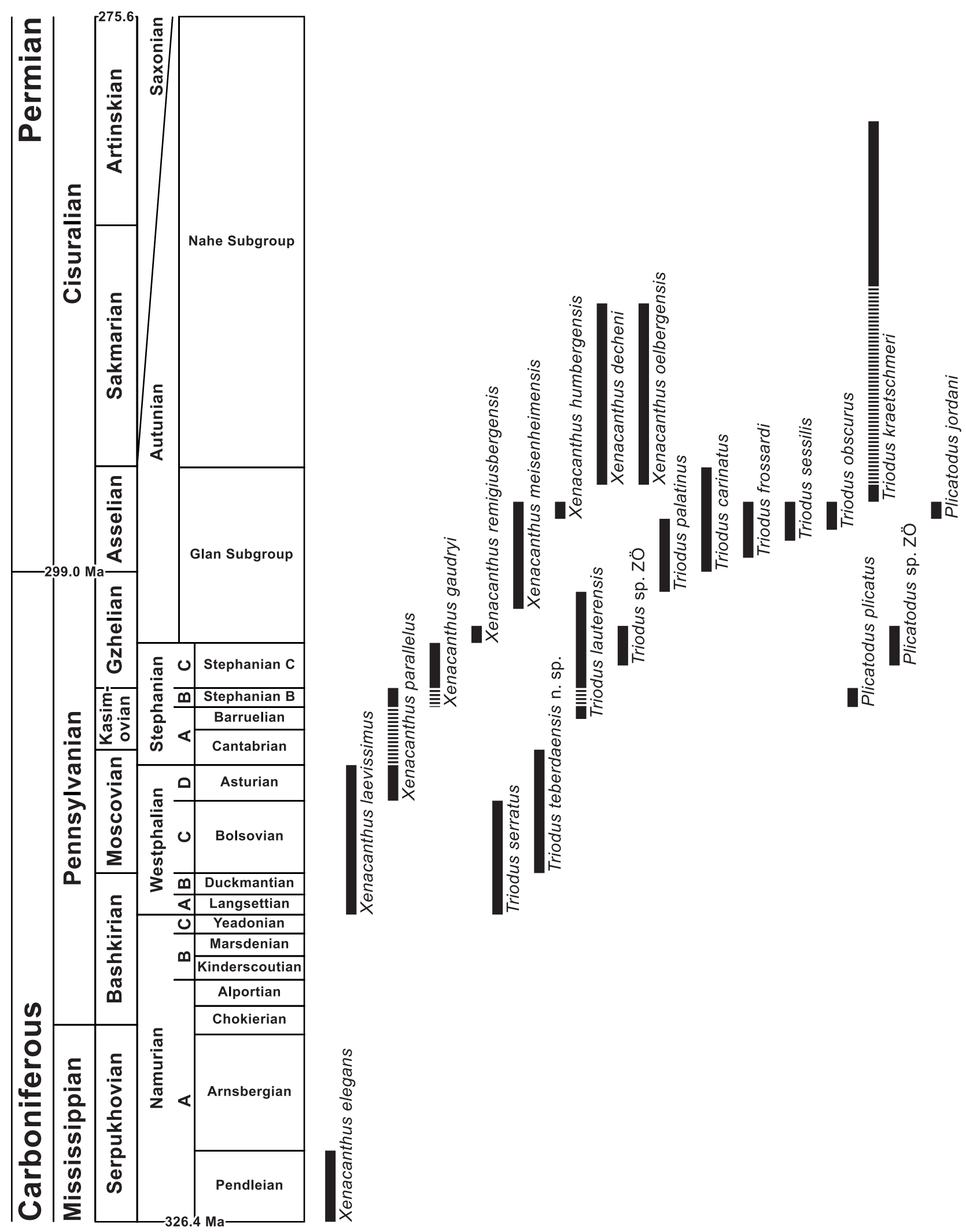

Fig. 5. Stratigraphical distribution of the Xenacanthidae (genera Xenacanthus, Triodus, Plicatodus) at least well known by their teeth (data from Boy \& Fichter 1988; Fritsch 1890; Gradstein et al. 2004; Hampe 1988, 1989, 1994, 1995, 2003 ; Menning et al. 2000; Schindler \& Hampe 1996; Schneider \& Zajíc 1994; Schneider et al. 1995, 2000; Soler-Gijón \& Hampe 1998). 
Table 1

Character matrix

\begin{tabular}{|c|c|c|c|c|c|c|c|c|c|c|c|c|c|}
\hline Character \# & 1 & 2 & 3 & 4 & 5 & 6 & 7 & 8 & 9 & 10 & 11 & 12 & 13 \\
\hline Dicentrodus bicuspidatus & 0 & 0 & 0 & 0 & 0 & 0 & 0 & 0 & 0 & 0 & 0 & 0 & 0 \\
\hline Triodus frossardi & 0 & 1 & 0 & 0 & $0 \& 1$ & 1 & 1 & $?$ & 0 & 0 & 1 & $?$ & $?$ \\
\hline Triodus carinatus & 0 & 0 & 0 & 1 & 0 & 1 & 0 & 0 & 0 & 1 & 0 & $?$ & $?$ \\
\hline Triodus serratus & 0 & 0 & 0 & 0 & 0 & 1 & 0 & 0 & 1 & 0 & 0 & 0 & 1 \\
\hline Triodus sp. ZÖ & 0 & 0 & 0 & 1 & 0 & 0 & 0 & $?$ & 0 & 1 & 0 & $?$ & $?$ \\
\hline Triodus kraetschmeri & 1 & 1 & 1 & 1 & 1 & 1 & 1 & 1 & 0 & 0 & 1 & 1 & 1 \\
\hline Triodus sessilis & 0 & 1 & 0 & 1 & 1 & 1 & 1 & 1 & 0 & 0 & 0 & 0 & 1 \\
\hline Triodus palatinus & 0 & 0 & 0 & 0 & 0 & 1 & 0 & 0 & 0 & 0 & 0 & 0 & 1 \\
\hline Triodus obscurus & 0 & 0 & 0 & 2 & 0 & 1 & 0 & 0 & 0 & 0 & 0 & $?$ & $?$ \\
\hline Triodus lauterensis & 0 & 0 & 0 & 0 & 0 & 0 & 0 & $?$ & 0 & 0 & 0 & 0 & 1 \\
\hline Triodus teberdaensis n. sp. & 1 & 1 & 0 & 1 & 0 & 1 & 1 & $?$ & 0 & 0 & 0 & $?$ & $?$ \\
\hline
\end{tabular}

Only the uppermost Pennsylvanian and Lower Permian depositional areas of the German SaarNahe Basin developed within the orogenic belt of the Variscan mountains. They became isolated after the uplift and are interpreted to be lake deposits (e.g., Boy 1976, 1998, 2003; Clausing 1993, 1998; Clausing et al. 1992).

Migrations of xenacanthid sharks have already been suggested in the past, e.g. for Orthacanthus kounoviensis (Hampe 1994, 2003). This species occurs in the Plzen Basin of Bohemia (Fritsch 1889), the Saale and the Saar-Nahe Basin (Hampe 1994; Schneider et al. 2000), in the Autun Basin (Heyler \& Poplin 1989; 1990 as O. buxieri) and probably in the Manchester Coalfield in England (Hampe 2003). The presence of O. kounoviensis in the various basins indicates the probability of interbasinal migrations or a faunistic exchange with the Palaeotethys.

The Pendleian (early Serpukhovian) Xenacanthus elegans could be the common ancestor of the Xenacanthidae. T. teberdaensis may have evolved from Xenacanthus elegans. The teeth of both species show several morphological affinities (see Discussion). T. sessilis, T. frossardi and T. kraetschmeri can be considered direct successors of T. teberdaensis, on the basis of the phylogenetic results and their stratigraphical distribution (Fig. 5).

\section{Acknowledgements}

We are grateful to Leonid Chegodaev (Essentuki) who provide the dissolved sample and stratigraphic information. We also express our cordial thanks to Elke Siebert (Berlin), who re-arranged and redrew the figures. With Rodrigo Soler-Gijón (Berlin, Madrid) we had several fruitful discussions. Linda Tsuji (Berlin) kindly reviewed the English. Additionally, we are indebted to Chris J. Duffin (London), Michał Ginter (Warsaw), and one anonymous referee for their careful review and important suggestions.

This paper is a contribution to the IGCP 491 "Middle Palaeozoic Vertebrate Biogeography, Palaeogeography and Climate: Middle Palaeozoic vertebrates of Laurussia: relationships with Siberia, Kazakhstan, Asia and Gondwana”.

\section{References}

Belov, A. A. \& Kizevalter, D. C. 1962. General features of structure and development history of Late Hercynian structural stage in the central part of Northern Caucasus (Middle Carboniferous - Lower Triassic). - Trudy Kavkazskoy Ekspeditsii VAGT i MGU za 1959-1960 3: 275-314.

Berg, L. S. 1940. Sistema ryboobraznykh i ryb, nyne zhivushchikh i ickopaemykh. - Trudy Zoologicheckogo instituta Akademii nauk SSSR 5 (2): 87-345.

Blieck, A., Conti, M. A., Dalla Vecchia, F. M., Flügel, H. W., Gand, G., Hubmann, B., Lelièvre, H., Mariotti, N., Nicosia, U., Poplin, C., Schneider, J. W. \& Werneburg, R. 1997. Palaeozoic vertebrates of the Alps: a review. - Bulletin de la Société Géologique de France 168 (3): 343-350.

Bonaparte, C. L. P. 1838. Introduzione alla Classie IV. Pesci. Iconografia della Fauna Italica per le quattro Classi degli Animali Vertebrati. Vol. 3, 16 pp., Salviucci, Roma.

Boy, J. A. 1976. Überblick über die Fauna des saarpfälzischen Rotliegenden (Unter-Perm). - Mainzer geowissenschaftliche Mitteilungen 5: 13-85.

- 1998. Möglichkeiten und Grenzen einer ÖkosystemRekonstruktion am Beispiel des spätpaläozoischen lakustrinen Paläo-Ökosystems. 1. Theoretische und methodische Grundlagen. - Paläontologische Zeitschrift 72 (1/2): 207-240.

- 2003. Paläoökologische Rekonstruktion von Wirbeltieren: Möglichkeiten und Grenzen. - Paläontologische Zeitschrift 77 (1): 123-152.

Boy, J. A. \& Fichter, J. 1988. Zur Stratigraphie des höheren Rotliegend im Saar-Nahe-Becken (Unter-Perm; SWDeutschland) und seiner Korrelation mit anderen Gebieten. - Neues Jahrbuch für Geologie und Paläontologie Abhandlungen 176 (3): 331-394.

Clausing, A. 1993. Mikro-Organofazies lakustriner Horizonte im saarpfälzischen Rotliegend (Permokarbon; SWDeutschland). - In Daber, R., Rüffle, L. \& Wendt, P. B. (eds). Pflanzen der geologischen Vergangenheit. Festschrift Prof. W. Krutzsch: 61-72, GSFP, Berlin.

- 1998. Sedimentologie und Paläoökologie unterpermischer Seen in Mitteleuropa. 2. Schorrenwald-See (Rotliegend; Saar-Nahe-Becken). - Mainzer geowissenschaftliche Mitteilungen 27: 45-66.

Clausing, A., Schmidt, D. \& Schindler, T. 1992. Sedimentologie und Paläoökologie unterpermischer Seen in Mitteleuropa. 1. Meisenheim-See (Rotliegend; Saar-Nahe-Becken). Mainzer geowissenschaftliche Mitteilungen 21: 159-198.

Crônier, C. \& Courville, P. 2005. New xiphosuran merostomata from the Upper Carboniferous of the Graissessac Basin (Massif Central, France). - Comptes Rendus Palevol 4: 123-133.

Fischer, J., Schneider, J. W., Ronchi, A., Pittau, P., Werneburg, R. \& Elicki, O. 2003. Haie und Amphibien aus dem 
Permokarbon von Sardinien - Wege über das Orogen? Terra nostra 2003 (5): 46-47.

Freytet, P., Galtier, J., Ronchi, A., Schneider, J. W., Tintori, A. \& Werneburg, R. 2002. Early Permian continental biota from Southeastern Sardinia (Ogliastra and Gerrei). Rendiconti della Società Paleontologica Italiana 1: 169_ 176.

Fritsch, A. 1889. Fauna der Gaskohle und der Kalksteine der Permformation Böhmens, Vol. 2 (4): 93-114, Řivnáč, Prag.

- 1890. Fauna der Gaskohle und der Kalksteine der Permformation Böhmens, Vol. 3 (1): 1-48, Řivnáč, Prag.

Glikman, L. S. 1964. Klass Chondrichthyes, Podklass Elasmobranchii. - In Orlov, Yu. A. (ed.). Osnovy Paleontologii, 11. Agnathes, Pisces: 195-236. Nauka, Moskva.

Goloboff, P. 1999. NONA (NO NAME) ver. 2. - published by the author, Tucumán, Argentina.

Gradstein, F. M., Ogg, J. G. \& Smith, A. G. 2004 (eds). A geologic time scale. - 589 pp., University Press, Cambridge.

Hairapetian, V., Ginter, M. \& Grigoryan, A. 2005. Description of stops. - In Hairapetian, V. \& Ginter, M. (eds). IGCP 491 Meeting. Devonian vertebrates of the continental margins. Field trip Guidebook. Yerevan, May 2005: 7-13, Islamic Azad University, Esfahan, Iran.

Hammer, Ø. \& Harper, D. A. T. 2006. Paleontological data analyses. - 351 pp., Blackwell Publishing, Malden, MA.

Hampe, O. 1988. Uber die Bezahnung des Xenacanthus (Chondrichthyes: Xenacanthida; Unterperm, SW-Deutschland). - Neues Jahrbuch für Geologie und Paläontologie Monatshefte 1988 (12): 743-756.

- 1989. Revision der Triodus-Arten (Chondrichthyes: Xenacanthida) aus dem saarpfälzischen Rotliegenden (Oberkarbon-Perm, SW-Deutschland) aufgrund ihrer Bezahnung. - Paläontologische Zeitschrift 63 (1/2): 79-101.

- 1994. Neue Erkenntnisse zur permokarbonischen Xenacanthiden-Fauna (Chondrichthyes: Elasmobranchii) und deren Verbreitung im südwestdeutschen Saar-NaheBecken. - Neues Jahrbuch für Geologie und Paläontologie Abhandlungen 192 (1): 53-87.

- 1995. Plicatodus jordani n.g., n. sp., a new xenacanthid shark from the Lower Permian of Europe (Saar-Nahe Basin, Germany). - In Arsenault, M., Lelièvre, H. \& Janvier, P. (eds). VIIth International Symposium, Studies on Early Vertebrates, 9-22 June 1991, Miguasha Parc, Quebec. - Bulletin du Muséum National d'Histoire Naturelle Section C: Sciences de la Terre, $4^{\mathrm{e}}$ Série 17 (1-4): 209226.

- 1997. Dental growth anomalies and morphological changes in teeth of the Xenacanthida (Lower Permian; Saar-Nahe basin, SW-Germany). - Modern Geology 21 (1/2): 121 135.

- 2003. Revision of the Xenacanthida (Chondrichthyes: Elasmobranchii) from the Carboniferous of the British Isles. - Transactions of the Royal Society of Edinburgh: Earth Sciences 93 (3): 191-237.

Hampe, O. \& Heidtke, U. H. J. 1997. Hagenoselache sippeli n. gen. n. sp., ein früher xenacanthider Elasmobranchier aus dem Oberkarbon (Namurium B) von Hagen-Vorhalle (NW-Sauerland/ Deutschland). - Geologie und Paläontologie in Westfalen 47: 5-42.

Heidtke, U. H. J., Schwind, C. \& Krätschmer, K. 2004. Über die Organisation des Skelettes und die verwandtschaftlichen Beziehungen der Gattung Triodus Jordan 1849 (Elasmobranchii: Xenacanthida). - Mainzer geowissenschaftliche Mitteilungen 32: 9-54.

Heyler, D. \& Poplin, C. M. 1988. The fossils of Montceau-lesMines. - Scientific American 256 (9): 104-110.

- 1989. Systematics and relationships among the Xenacanthiformes (Pisces, Chondrichthyes) in the light of Carboniferous and Permian French material. - Acta Musei Reginaehradecensis A 22: 69-78.
- 1990. Les Vertébrés autuniens de Buxières-les-Mines (Allier, France). - Bulletin du Muséum National d'Histoire Naturelle, $4^{\mathrm{e}}$ série, Section C 12 (2): 225-239.

Huxley, T. H. 1880. On the application of the laws of evolution to the arrangement of the Vertebrata, and more particularly of the Mammalia. - Proceedings of the Scientific Meetings of the Zoological Society of London 1880: 649-662.

Ivanov, A. 2003. Vertebrates from the Late Devonian - Carboniferous of North Caucasus (Russia). - Ichthyolith Issues Special Publication 7: 27-28.

Johnson, G. D. 1999. Dentitions of Late Palaeozoic Orthacanthus species and new species of ?Xenacanthus (Chondrichthyes: Xenacanthiformes) from North America. Acta Geologica Polonica 49 (3): 215-266.

Johnson, G. D. \& Thayer, D. W. 1999. Early Pennsylvanian xenacanth sharks from the Swisshelm Mountains, Arizona. - In Hills, L. \& Bamber, W. (eds). XIV International Congress on the Carboniferous and Permian Programme with Abstracts: 68 .

Jordan, H. 1849. Triodus sessilis, ein neuer Fisch der Kohlenformation von Lebach. - Neues Jahrbuch für Mineralogie, Geologie und Paläontologie 1849: 843.

Kner, R. 1867. Über Orthacanthus dechenii Goldf. oder Xenacanthus dechenii Beyr. - Sitzungsberichte der Mathematisch-Naturwissenschaftlichen Classe der Kaiserlichen Akademie der Wissenschaften 55: 540-584.

Lebedev, O. A. 2005. Vertebrate microremains from the Upper Famennian - Lower Tournaisian Geran-Kalasy section (Nakhichevan, Azerbaijan). - Ichthyolith Issues Special Publication 8: 19.

Menning, M., Weyer, D., Drozdzewski, G., van Amerom, H. W. J. \& Wendt, I. 2000. A Carboniferous time scale 2000: Discussion and use of geological parameters as time indicators from Central and Western Europe. - Geologisches Jahrbuch A 156: 3-44.

Nixon, K. C. 2002. WinClada ver. 1.00.08. - published by the author, Ithaca, New York.

Pogrebnov, N. I. 1975 (ed.). Field excursion guidebook for the Donets Basin and North Caucasus. - The VIII International Congress on Carboniferous Stratigraphy and Geology, 1975, Moscow, USSR, 104 pp., Nauka, Moskva.

Savin, S.V. 1984 (ed.). Guidebook for excursions on the Caucasus and Eastern Donbass. - The 27th International Geological Congress, 1984, Moscow, USSR, 215 pp., Nauka, Moskva.

Schindler, T. \& Hampe, O. 1996. Eine erste Fischfauna (Chondrichthyes, Acanthodii, Osteichthyes) aus dem Permokarbon Niederösterreichs (Zöbing, NE Krems) mit paläoökologischen und biostratigraphischen Anmerkungen. Beiträge zur Paläontologie 21: 93-103.

Schneider, J. W. \& Zajíc, J. 1994. Xenacanthiden (Pisces, Chondrichthyes) des mitteleuropäischen Oberkarbon und Perm - Revision der Originale zu Goldfuss 1847, Beyrich 1848, Kner 1867 und Fritsch 1879-1890. - Freiberger Forschungshefte C452: 101-151.

Schneider, J. W., Hampe, O. \& Soler-Gijón, R. 2000. The Late Carboniferous and Permian: Aquatic vertebrate zonation in southern Spain and German basins. - Courier Forschungsinstitut Senckenberg 223: 543-561.

Schneider, J. W., Rössler, R. \& Gaitzsch, B. 1995. Time lines of the Late Variscan volcanism - a holostratigraphic synthesis. - Zentralblatt für Geologie und Paläontologie. Teil 11994 (5/6): 477-490.

Schneider, J. W., Ronchi, A., Pittau, P. Werneburg, R. \& Elicki, O. 2003. Carboniferous/Permian fishs and amphibians of Sardinia - problems of biostratigraphic correlations across the Variscan watershed. - XVth International Congrerss on Carboniferous and Permian stratigraphy, Abstracts: 474-478, University of Utrecht.

Schultze, H.-P. \& Soler-Gijón, R. 2004. A xenacanth clasper from the ?uppermost Carboniferous - Lower Permian of Buxières-les-Mines (Massif Central, France) and the 
palaeoecology of the European Permo-Carboniferous basins. - Neues Jahrbuch für Geologie und Paläontologie Abhandlungen 232 (2/3): 325-363.

Soler-Gijón, R. 1993. Estudio de los vertebrados fósiles del Carbonífero superior de Puertollano, Ciudad Real. 239 pp., Universidad Complutense Madrid [unpublished Ph.D. thesis].

- Los vertebrados del Carbonífero superior de Puertollano (Ciudad Real): Registro e implicationes. - In Aguirre, E. \& Rábano, I. (eds). La huella del pasado fósiles de CastillaLa Mancha: 99-112, Junta de Comunidades de CastillaLa Mancha, Toledo.

Soler-Gijón, R. \& Hampe, O. 1998. Evidence of Triodus Jordan 1849 (Elasmobranchii: Xenacanthidae) in the Lower Permian of the Autun basin (Muse, France). - Neues
Jahrbuch für Geologie und Paläontologie Monatshefte 1998 (6): 335-348.

Vai, G. B. 2003. Development of the palaeogeography of Pangaea from Late Carboniferous to Early Permian. Palaeogeography, Palaeoclimatology, Palaeoecology 196: 125-155.

Wells, M. R., Allison, P. A., Hampson, G. J., Piggott, M. D. \& Pain, C. C. 2005. Modelling ancient tides: the Upper Carboniferous epi-continental seaway of Northwest Europe. Sedimentology 52(4): 715-735.

Zajíc, J. \& Štamberg, S. 1985. Summary of the Permocarboniferous freshwater fauna of the limnic basins of Bohemia and Moravia. - Acta Musei Reginaehradecensis A 20: 61-82.

Ziegler, P. A. 1989. Evolution of Laurussia: a study in Late Palaeozoic plate tectonics. - 102 pp., Kluwer, Dordrecht. 